University of Nebraska - Lincoln

DigitalCommons@University of Nebraska - Lincoln

April 1994

\title{
A Comparison of Deterrents to College-bound Male and Female Enrollment in Secondary Agricultural Education Programs in Nebraska
}

\author{
Lloyd C. Bell \\ University of Nebraska - Lincoln, lbell1@unl.edu \\ Susan Fritz \\ University of Nebraska - Lincoln, sfritz1@unl.edu
}

Follow this and additional works at: https://digitalcommons.unl.edu/aglecfacpub

Part of the Other Public Affairs, Public Policy and Public Administration Commons

Bell, Lloyd C. and Fritz, Susan, "A Comparison of Deterrents to College-bound Male and Female Enrollment in Secondary Agricultural Education Programs in Nebraska" (1994). Faculty Publications: Agricultural Leadership, Education \& Communication Department. 7.

https://digitalcommons.unl.edu/aglecfacpub/7

This Article is brought to you for free and open access by the Agricultural Leadership, Education \& Communication Department at DigitalCommons@University of Nebraska - Lincoln. It has been accepted for inclusion in Faculty Publications: Agricultural Leadership, Education \& Communication Department by an authorized administrator of DigitalCommons@University of Nebraska - Lincoln. 


\title{
A Comparison of Deterrents to Collegebound Male and Female Enrollment in Secondary Agricultural Education Programs in Nebraska
}

\author{
Lloyd C. Bell, Assistant Professor \\ Susan Fritz, Assistant Professor \\ University of Nebraska
}

Who influences students' decisions to enroll in traditional and/or nontraditional programs? Encouragement from parents to succeed in math, science and technology is critical in a girl's decision to enroll in these courses (Parsons, 1980). Beck (1989) contended that the greatest influence on anyone's career decision, regardless of gender, is the mother. Kotrlik and Harrison (1987) reported in their study that "for agricultural education students as well as other seniors, parents influenced the students' career choices more than any other person, with the mother being more influential than the father." Guidance counselors had almost no impact on informing students about what was taught in agricultural education programs (Luft \& Giese, 1991).

By analyzing the literature on women's occupational distribution and wage differentials, Lillydahl (1986) discovered explanations put forth by Becker, Phelps and Bergman related to the economic principle of supply and demand theory. Their explanations contribute toward a minimal demand premise in which females are non firstconsideration applicants for employment opportunities nontraditional for their gender. Conversely, considering the supply side theory, women accepting the demand premise of not being a first consideration applicant elect more traditional employment opportunities creating a comparatively large supply. The continuation of this demand situation contributes to occupational crowding and lower relative wages. The demand premise is steeped in cultural bias; the supply premise is a phenomenon of acceptance. Advances have been made in nontraditional enrollments, but those women and men who enroll in nontraditional programs face a number of problems none of the least being "sex bias and stereotyping; harassment; lack of support by family, school personnel and peers; lack of guidance programs; lack of role models; and job placement (Imel, 1989)." To continue to make strides in nontraditional enrollments in vocational courses, deterrents need to be addressed.

In a study conducted by Bell and Fritz (1992) females who had access to secondary agricultural education courses but chose not to enroll, but who subsequently enrolled in the College of Agricultural Sciences and Natural Resources, University of Nebraska-Lincoln were surveyed to determine deterrents to their secondary agricultural education enrollment. Critical obstacles identified were lack of career information explaining both traditional and nontraditional employment opportunities for females, a lack of counselor services providing awareness of nontraditional employment and career opportunities, a lack of an existing supportive network for participation in agricultural education courses, an agricultural education program delivery format not responsive to their needs, and difficulty in scheduling agricultural education courses. The majority of these deterrents were not gender-specific and could have been experienced by both males and females. Follow-up research was recommended with a male audience paralleling the educational background of the female audience surveyed in the research. The purpose being to compare considerations influencing their decision to not enroll to those of the female audience previously surveyed.

\section{Purpose and Objectives}

The purpose of this investigation was to identify and define deterrents to male enrollment in secondary agricultural education programs in Nebraska and compare and contrast the results to responses of females in a similar study conducted in Nebraska in Fall, 1990. The objectives of the study were to:

Identify critical considerations made by male students which influenced their decision of whether to enroll in agricultural 
education classes.

Compare and contrast male and female responses regarding critical considerations which influenced their decision of whether to enroll in agricultural education classes.

\section{Procedures}

$\underline{\text { Ponulations }}$

The populations of this study were resident males who graduated from high schools offering agricultural education who were majoring in an area of study in the College of Agricultural Sciences and Natural Resources (CASNR), University of Nebraska-Lincoln and had not enrolled in agricultural classes at the high school level and resident females who graduated from high schools offering agricultural education who were majoring in an area of study in the CASNR, University of Nebraska-Lincoln and had not enrolled in agricultural classes at the high school level.

Group I, males, had a population of 49, 36 responded for a response rate of $74 \%$; group 2 , females, had a population of 37,30 responded for a response rate of 81 percent. The reliability for each group was .93 and .95 , respectively.

The populations were identified by a confidential search of secondary transcripts found in files in the Dean's Office, CASNR. Because of the relatively small number, (Group 1, $\mathrm{N}=49$ and Group 2, $\mathrm{N}=37$ ), the total population was surveyed. In order to assure researcher familiarity with secondary schools offering agricultural education, high schools offering programs were verified from an official agricultural education roster provided by the Nebraska Department of Education.

\section{Instrumentation}

Instrumentation was a questionnaire derived from a review of relevant literature and corresponded to the objectives of the female study. The instrument consisted of demographic questions and attitudinal questions related to courses, support networks, guidance, career awareness, facilities, others' perception of enrollment in agricultural classes and school policy. A four-point Likert-type scale ( $1=$ strongly agree to $4=$ strongly disagree) was used for response to attitudinal questions.
The instrument was reviewed for content validity by a panel of experts including teacher educators, educational psychologists, graduate students, counselors, equity specialists and female college students.

\section{Data Collection}

A questionnaire package was mailed containing the coded survey, cover letter and stamped, return envelope. Initial follow-up of nonrespondents was a phone call after two weeks.

\section{Treatment of the Data}

Data were treated using the Statistical Packages for the Social Sciences program. T-test comparisons of early and late respondents yielded no significant differences (.05).

\section{Findings}

Data were reviewed regarding critical considerations made by college males and the degree to which these considerations influenced their decision to not enroll in agricultural education courses. It was observed that no considerations were identified by the respondents as "strongly agreeing" (1.5 rating or lower on a 4-point Likerttype scale) to their influence. They did agree to a lesser extent (score of 1.5 to 2.5 ) on the influence three considerations made on their decision to not enroll in agricultural education courses. The remaining seventeen items did not influence their decisions to not enroll (scores of 2.6 to 4.0).

Male students agreed the following were considerations that influenced their decision to not enroll in secondary agricultural education courses:

Lack of career information explaining opportunities in the agricultural industry.

Course content was not relevant to current and future employment opportunities in the agricultural industry.

Agricultural education course content based on a year-long program including many different agricultural topics was not responsive to their specific interest in agriculture. 
Data were compared regarding critical considerations made by college males and females and the degree to which there was practical difference between responses by gender. Practical difference was set by the researchers as 0.5 or greater in mean scores. Two items were identified.

A practical difference existed between male and female responses to the influence of the following:

Lack of career information explaining opportunities in the agricultural industry (although both mean responses were within the agreement range).

Males/Females already enrolled or having completed the agricultural education course or program influenced your decision.

\section{Conclusions and Recommendations}

The following conclusions were drawn from the findings of this study:

Males who did not have agricultural education courses in secondary were available but chose to enroll in a college of agriculture felt they lacked career information explaining career opportunities in the agricultural industry. Beck (1989) suggested lack of career information is a deterrent to nontraditional student enrollment. The results of the male study would indicate lack of career information transcends the gender boundary and is a problem for all nontraditional students.

The findings of this study support those of the National research Council (1988) in that course content of some agricultural education programs have not kept pace with changing and emerging career areas of agriculture. Male students particularly were not finding course content or delivery format that were aligned with their specific agricultural interests.

Males indicated stronger disagreement than females when responding to "the school counselor advised them not to enroll." Lillydahl's (1986) research supports this conclusion. Counseling is either consciously or unconsciously influenced by the perception of "gender appropriate" occupational roles and is a phenomenon of acceptance.
Males were influenced to a greater degree to not enroll in agricultural education courses by other males or females already enrolled or having completed an agricultural education course of program. Historically, males have been the traditional participants of secondary agricultural education. It is likely a greater concentration of contact with participating males would be available to other males. A partial explanation for this significance, according to linguist Deborah Tannin (199 1), may lie in the premise that for males "life is a contest, a struggle to preserve independence and avoid failure." Males may be more sensitive to participant opinion.

Comparisons in this study between males and females indicate no one group (peers, counselors, instructor, mother or father) had a significant impact on the students' decision to enroll. These findings run contrary to Kotrlik and Harrisons' (1987) conclusion that parents influenced students' decisions more than any other group. There was a significant degree of difference between male and female response to "mother's support of the decision to enroll in agricultural education," but it may be due again to "gender appropriateness" as determined by Lillydahl's (1986) research. The following recommendations are made as a result of this study:

All students, regardless of gender, need more career information explaining career opportunities in the agricultural industry. The career information should be genderless and should be progressive, addressing traditional and emerging careers. It should contain information about education requirements and salary ranges. It should be reinforced by networking with former students pursuing post-secondary education and potential role models.

Because of the politically sensitive nature of a guidance counselor marketing one program over another, agricultural education instructors should meet and provide counselors with concise, clear, genderless course descriptions in flyer or brochure format students may pick up. The descriptions should indicate the relevance of the course to them, the essence of the course objectives and indicate career areas within agricultural industry that are related to the course content.

Students need to be advised, regardless of 
Table 1. Comparisons of Male and Female Responses to Degrees to Which Considerations Influenced Decisions to Not Enroll in Secondary Agricultural Education Courses

\begin{tabular}{|c|c|c|c|c|}
\hline \multirow{3}{*}{ was a lack of career information explaining onnortunitie } & Gender & $\mathrm{N}$ & \multirow{2}{*}{$\frac{\text { Mean }}{2.44}$} & \multirow{2}{*}{$\frac{\mathrm{SD}}{.88}$} \\
\hline & $\mathrm{M}$ & 32 & & \\
\hline & $\mathrm{F}$ & 28 & 1.75 & .84 \\
\hline The school counselor provided no guidance about the high school & M & 29 & 3.38 & .62 \\
\hline You perceived that agricultural education course content was not relevant & int $\mathrm{F}$ & $\begin{array}{l}23 \\
32\end{array}$ & $\begin{array}{l}3.17 \\
2.28\end{array}$ & $\begin{array}{l}.94 \\
85\end{array}$ \\
\hline $\begin{array}{l}\text { to current and future employment opportunities in the agricultural } \\
\text { industry. }\end{array}$ & $\mathrm{F}$ & 28 & 2.54 & .84 \\
\hline Agricultural education course content based on a year-long program & M & 24 & 2.21 & .72 \\
\hline $\begin{array}{l}\text { (Ag I II, III, IV) including many different agricultural topics which } \\
\text { were not responsive to your specific interest in agriculture. }\end{array}$ & $\mathrm{F}$ & 24 & 2.33 & .76 \\
\hline Agricultural education courses were not easily scheduled. & $\begin{array}{l}\mathrm{M} \\
\mathrm{F}\end{array}$ & $\begin{array}{l}31 \\
25\end{array}$ & $\begin{array}{l}2.55 \\
2.52\end{array}$ & .85 \\
\hline $\begin{array}{l}\text { Course titles and descriptions of agricultural education classes did not } \\
\text { accurately describe course content using gender-neutral language. }\end{array}$ & $\begin{array}{l}\mathrm{M} \\
\mathrm{F}\end{array}$ & $\begin{array}{l}24 \\
22\end{array}$ & $\begin{array}{l}2.58 \\
2.77\end{array}$ & .83 \\
\hline $\begin{array}{l}\text { The instructor of agricultural education provided no guidance about the } \\
\text { high school agricultural education program. }\end{array}$ & $\begin{array}{l}\text { M } \\
\mathrm{F}\end{array}$ & $\begin{array}{l}28 \\
24\end{array}$ & $\begin{array}{l}2.57 \\
2.71\end{array}$ & .88 \\
\hline $\begin{array}{l}\text { The agricultural education teacher lacked professional appearance and/or } \\
\text { conduct. }\end{array}$ & $\begin{array}{l}\text { M } \\
F\end{array}$ & $\begin{array}{l}30 \\
27\end{array}$ & $\begin{array}{l}2.87 \\
3.19\end{array}$ & .90 \\
\hline $\begin{array}{l}\text { You chose not to enroll in agricultural courses primarily because of the } \\
\text { influence from vour friends (peers). }\end{array}$ & $\begin{array}{l}\text { M } \\
\mathrm{F}\end{array}$ & $\begin{array}{l}28 \\
24\end{array}$ & 2.86 & 1.21 \\
\hline $\begin{array}{l}\text { A lack of a successful male/female role model in the agricultural career } \\
\text { in which vou were interested. }\end{array}$ & $\begin{array}{l}\mathrm{M} \\
\mathrm{F}\end{array}$ & 27 & 3.04 & .98 \\
\hline $\begin{array}{l}\text { Males/Females already enrolled or having completed the agricultural } \\
\text { education course or program influenced your decision. }\end{array}$ & $\begin{array}{l}\mathrm{M} \\
\mathrm{F}\end{array}$ & 31 & 2.61 & .84 \\
\hline The school counselor advised you not to enroll. & $\begin{array}{l}\mathrm{M} \\
\mathrm{F}\end{array}$ & $\begin{array}{l}29 \\
23\end{array}$ & $\begin{array}{l}3.34 \\
3.17\end{array}$ & .62 \\
\hline $\begin{array}{l}\text { You chose not to enroll in agricultural courses primarily because of the } \\
\text { influence from your school counselor. }\end{array}$ & $\begin{array}{l}\mathrm{M} \\
\mathrm{F}\end{array}$ & $\begin{array}{l}25 \\
23\end{array}$ & $\begin{array}{l}3.40 \\
2.96\end{array}$ & $\begin{array}{l}.74 \\
.88\end{array}$ \\
\hline $\begin{array}{l}\text { You chose not to enroll in agricultural courses primarily because of the } \\
\text { influence from your mother. }\end{array}$ & $\begin{array}{l}\text { M } \\
\mathrm{F}\end{array}$ & $\begin{array}{l}25 \\
24\end{array}$ & $\begin{array}{l}3.32 \\
3.25\end{array}$ & $\begin{array}{r}1.03 \\
.94\end{array}$ \\
\hline $\begin{array}{l}\text { You chose not to enroll in agricultural courses primarily because of the } \\
\text { influence from your agricultural education instructor. }\end{array}$ & $\begin{array}{l}\mathrm{M} \\
\mathrm{F}\end{array}$ & $\begin{array}{l}26 \\
22\end{array}$ & $\begin{array}{l}2.92 \\
3.14\end{array}$ & $\begin{array}{r}1.01 \\
.83\end{array}$ \\
\hline A "close" friend did not support your enrollment in agricultural education & $\begin{array}{l}\mathrm{n} \\
\mathrm{F}\end{array}$ & $\begin{array}{l}27 \\
26\end{array}$ & $\begin{array}{l}3.22 \\
3.11\end{array}$ & .89 \\
\hline Your mother did not support you decision to enroll. & $\begin{array}{l}\mathrm{M} \\
\mathrm{F}\end{array}$ & $\begin{array}{l}32 \\
26\end{array}$ & $\begin{array}{l}3.59 \\
3.19\end{array}$ & $\begin{array}{l}.76 \\
.85\end{array}$ \\
\hline $\begin{array}{l}\text { You chose not to enroll in agricultural courses primarily because of the } \\
\text { influence from your father. }\end{array}$ & $\begin{array}{l}\text { M } \\
\text { F }\end{array}$ & $\begin{array}{l}25 \\
23\end{array}$ & $\begin{array}{l}3.32 \\
3.52\end{array}$ & $\begin{array}{c}1.03 \\
59\end{array}$ \\
\hline Your father did not support your decision to enroll. & $\begin{array}{l}\mathrm{M} \\
\mathrm{F}\end{array}$ & $\begin{array}{l}32 \\
24\end{array}$ & $\begin{array}{l}3.56 \\
3.42\end{array}$ & .72 \\
\hline The instructor of agricultural education & $\begin{array}{l}\mathrm{M} \\
\mathrm{F}\end{array}$ & $\begin{array}{l}30 \\
23\end{array}$ & $\begin{array}{l}3.42 \\
3.53\end{array}$ & $\begin{array}{l}.05 \\
.61 \\
.59\end{array}$ \\
\hline
\end{tabular}

Note: Mean calculated from a scale of $1=$ strongly agree to $4=$ stongly disagree. Disagree defined as 2.6-4.0.

gender, to enter into programs in which they indicate an interest. Opportunities such as a junior high exploratory course using the discovery learning method could expose students to the range of possibilities agriculture could hold for them.
Students in this study by-passed secondary agricultural education, but still elected an area of study in CASNR at the University of NebraskaLincoln related to a potential career. It may be they found post secondary curriculum more relevant to 
their career interests than their secondary agricultural education curriculum. Secondary instructors looking to update programs may want to consider aligning their courses with courses/careers offered in post-secondary institutions.

Because of the limiting nature of the quantitative study method, it is recommended a qualitative study be conducted with students from the population to obtain detail regarding their decisions not to enroll in agricultural education at the secondary level.

\section{R eferences}

Beck, J. (1989). Step bv step. A seven step process for increasing the enrollment of women and girls in Non-traditional programs. (pp. 2-6). Washington, D.C.: Wider Opportunities for Women.

Bell, L.C. \& Fritz, S.M. Deterrents to female enrollment in agricultural education programs in Nebraska. Journal of Agricultural Education, 33(4): 39-47.

Imel, S. (1989). Nontraditional occupations: A status report. Alerts. trends and issues. (Eric Document Reproduction Service No. Ed 304 564.

Kotrlik, J.W. \& Harrison, B.C. (1987). Factors related to the career decisions of seniors who have taken vocational agriculture. The Journal of the American Association of Teacher Educators in Agriculture, 28(4): 50-56.

Lillydahl, J.J. (1986). Women and traditionally blue collar jobs. Work and Occupations, 13(3): 303-323.

Luft, V.D. \& Giese, D.A. (1991). Factors and persons influencing high school students to enroll in vocational agriculture programs. In L.R. Arrington (ed.), Proceedings of the National Agricultural Education Research Meeting (pp. 71-77). Los Angeles, CA.

National Research Council and Committee on Agricultural Education in Secondary Schools (1988). Understanding agriculture - new directions for education (pp. 1-7). National Academy Press. Washington, D.C.

Parsons, J . (1980). Self-Percentions. task perceptions and academic choice: origins and change. Michigan: National Institute of Education.

Tannen, D. (1991). You just don't understand.

New York: Ballentine. 